\title{
Baseline Sensitivity of Guignardia citricarpa Isolates from Florida to Azoxystrobin and Pyraclostrobin
}

Martha Hincapie, Gulf Coast Research and Education Center, University of Florida, Wimauma; Nan-Yi Wang, Citrus Research and Education Center, University of Florida, Lake Alfred; Natalia A. Peres, Gulf Coast Research and Education Center, University of Florida, Wimauma; and Megan M. Dewdney, Citrus Research and Education Center, University of Florida, Lake Alfred

\begin{abstract}
Hincapie, M., Wang, N.-Y., Peres, N. A., and Dewdney, M. M. 2014. Baseline sensitivity of Guignardia citricarpa isolates from Florida to azoxystrobin and pyraclostrobin. Plant Dis. 98:780-789.

Citrus black spot (CBS), caused by Guignardia citricarpa, is an emerging disease in Florida. Fungicide applications are the main control measure worldwide. The in vitro activity and baseline sensitivity of G. citricarpa isolates to quinone outside inhibitor (QoI) fungicides (azoxystrobin and pyraclostrobin) were evaluated. The effective concentration needed to reduce mycelial growth or spore germination by $50 \%\left(\mathrm{EC}_{50}\right)$ was determined for 86 isolates obtained from Florida counties where CBS is found. The effect of salicylhydroxamic acid (SHAM) plus azoxystrobin and pyraclostrobin was also assessed for mycelial growth and conidial germination. The mean $\mathrm{EC}_{50}$ for mycelial

was significantly lower at $0.007 \mu \mathrm{g} / \mathrm{ml}(P<0.0001)$. Similarly, the mean $\mathrm{EC}_{50}$ for conidial germination for azoxystrobin was $0.016 \mu \mathrm{g} / \mathrm{ml}$ and that for pyraclostrobin was significantly lower at $0.008 \mu \mathrm{g} / \mathrm{ml}(P<$ 0.0001). There was no effect of SHAM on inhibition of mycelial growth or conidial germination by the QoI fungicides but SHAM slightly affected mycelium inhibition by pyraclostrobin. Cytochrome $b$ was partially sequenced and three group 1 introns were found. One intron was immediately post G143, likely inhibiting resistance-conferring mutations at that site. It is surmised that the QoI resistance risk is low in the Florida G. citricarpa population.
\end{abstract} growth for azoxystrobin was $0.027 \mu \mathrm{g} / \mathrm{ml}$ and that for pyraclostrobin
Citrus black spot (CBS), caused by Guignardia citricarpa Kiely, anamorph Phyllosticta citricarpa (McAlpine) Van der Aa, was found in Collier County, FL in April 2010 (47). Most commercially grown citrus species, including grapefruit, tangerine, sweet orange, and lemon, are susceptible to CBS (11). The disease causes extensive blemishes on the fruit rind affecting the appeal for the fresh market, although the internal quality remains unaffected. In addition, premature fruit drop may occur, reducing crop yield $(6,54)$.

The pathogen is found in many of the subtropical citrus production zones and is considered a very economically important citrus disease with severe crop losses because fruit are no longer marketable and can abscise prematurely. The disease was first described in New South Wales, Australia in $1895(5,41)$. It has since spread to the subtropical regions of many citrus-producing countries such as Argentina, Brazil, China, Ghana, Indonesia, Kenya, Mozambique, Philippines, South Africa, Taiwan, Uruguay, Uganda, Venezuela, Zambia, and Zimbabwe $(11,41,61)$. The disease, however, has not been reported in Mediterranean countries or production regions $(5,41,61)$.

Currently, in Florida, three counties (Collier, Hendry, and Polk) are confirmed to have black spot and sections have been designated as quarantine areas by the United States Department of Agriculture Animal and Plant Health Inspection Service. Conditions to restrict the interstate movement of regulated articles (citrus fruit and plant parts such as leaves, budwood, and nursery stock) have been implemented. In addition to regulatory measures, control strategies must be undertaken. An economic assessment estimated the cost of

Corresponding author: M. M. Dewdney, E-mail: mmdewdney@ufl.edu

* The $e$-Xtra logo stands for "electronic extra" and indicates that a supplementary figure is available online.

Accession number: KC788404.

Accepted for publication 5 December 2013.

http://dx.doi.org/10.1094/PDIS-03-13-0335-RE

(C) 2014 The American Phytopathological Society
CBS control to be at least $\$ 220$ million annually in the United States; however, due to preventive copper sprays already used to control citrus canker, the actual cost may be not as high as predicted (27). In addition to the cost of control measures, it was forecast that there could be up to $\$ 847$ million of losses in Florida from CBS (27).

The humid subtropical conditions with high summer rainfall in Florida are favorable for the development of CBS (32). Predictive models used to determine the risk of CBS establishment after pathogen introduction to the United States found that Florida conditions are highly favorable for the disease and Texas is at moderate risk of introduction $(41,61)$. Other areas, such as California, have a low risk for disease development due to the lack of rainfall and prolonged leaf wetness periods that promote the disease $(41,61)$.

Hard spot is the most diagnostic preharvest symptom of CBS. The lesions are 3 to $10 \mathrm{~mm}$ in diameter, circular, depressed, with brick red to black margins and gray-white necrotic centers. On green fruit, the lesions may be surrounded by a yellow halo but can have a green halo on mature fruit $(9,32)$. Pycnidia are often found at the center of the lesion as slightly elevated black dots but ascocarps are never formed in fruit lesions $(9,32)$. False melanose, early virulent spot, virulent spot, and cracked spot are other fruit symptom types of black spot $(9,32)$. Fruit remain susceptible to infection for 4 to 5 months after petal fall (32). Leaf symptoms are rare and most often appear on lemon. Fruit peduncles can also show symptoms. When symptoms are present on leaves, lesions are small, round, and red-brown, sometimes with a yellow halo. As they age, a necrotic center forms, surrounded by a dark-brown margin. Leaves remain susceptible from development for up to 10 months (55).

Black spot control is based mainly on preventive applications of fungicides during the period of fruit susceptibility (48); nevertheless, cultural practices have been implemented in Florida to reduce inoculum and pathogen spread (17). In other areas where CBS is present, the disease is controlled with fungicides from different mode of action groups such as the benzimidazoles, quinone outside inhibitors (QoIs; strobilurins), dithiocarbamates, and copper products $(15,48)$. Currently in Florida, only QoI fungicides and copper are registered for the control of black spot. Monthly applications of copper and QoIs (azoxystrobin, pyraclostrobin, or trifloxystrobin) 
are recommended from early May to mid-September but there is a label limit of four QoI applications in a season. For this reason, it is suggested to reserve QoI fungicides for times when there is concern about copper phytotoxicity (temperatures exceeding $34^{\circ} \mathrm{C}$ ), especially when applied in orchards whose fruit is destined for the fresh market (17).

QoI fungicides block electron transport at the quinol-oxidizing site of the cytochrome $b$ complex (complex III) in the mitochondria, disrupting ATP production $(8,22)$. Spore germination is the fungal growth stage that is particularly sensitive to QoIs (8). Several plant pathogens can avoid the toxic effects of QoI fungicides by the expression of the alternative oxidase pathway (28). The alternative oxidase pathway takes place in the inner mitochondrial membrane (57) and it can be inhibited by salicylhydroxamic acid (SHAM) and $n$-propyl gallate $(46,50)$. For this reason, SHAM is usually added to QoI fungicides when tested in vitro (18). The addition of SHAM to azoxystrobin to in vitro tests with Sclerotinia sclerotiorum synergistically improved pathogen inhibition, compared with when azoxystrobin was used alone (18). Similarly, the mixture of SHAM and azoxystrobin in in vitro tests with Colletotrichum capsici and Botrytis cinerea showed a synergistic effect on mycelium inhibition (28).

The mode of action of QoI fungicides is highly specific, and many different pathogens have lost sensitivity to this group of fungicides due to a single-point mutation that leads to a change from glycine $(\mathrm{G})$ to alanine (A) at amino acid residue 143 in the cytochrome $b$ gene (G143A; 21,22,25). A second amino acid substitution shown to reduce sensitivity to QoI fungicides is the replacement of phenylalanine with leucine at position 129 (F129L; 40). A third amino acid substitution from glycine to arginine at the position 137 (G137R) was detected recently in Pyrenophora triticirepentis, conferring reduced sensitivity to $\mathrm{QoI}$ fungicides comparable with that of the F129L substitution (51).

Azoxystrobin (Abound 2.08F; Syngenta Crop Protection) and pyraclostrobin (Headline; BASF Crop Protection), two members of the QoI class of fungicides, have been reported to provide good control of black spot in the field as well as in in vitro studies $(1,19,35,44,48)$. Due to the site-specific mode of action of QoI fungicides, the potential for resistance development must be considered. Although G. citricarpa resistance to QoIs has not been reported, in vitro studies determined that mycelial growth was not completely inhibited even at high concentrations of azoxystrobin (43). On the other hand, the same author pointed out that the variation in sensitivity to the fungicide is possibly related to the genetic variability of $G$. citricarpa isolates.

Despite prolonged exposure to QoI fungicides, some fungi have yet to develop the high levels of resistance conferred by the G143A substitution $(23,24,34)$. In these fungi, it has been shown that a group I intron is often found inserted after the G143 codon whereas, in species where resistance occurs, no intron is present (23). Such an intron was found in a study on a small number of $G$. citricarpa isolates and G. bidwellii, a species closely related to $G$. citricarpa, and resistance has yet to occur for either fungus $(34,52)$. Little is known about the provenance of the Florida $G$. citricarpa population and whether the presence of the intron may vary, as it does in B. cinerea (7). QoI fungicides are currently key to CBS control in Florida; therefore, a resistance risk assessment is extremely important for the long-term management of the disease.

The baseline sensitivity of other Florida citrus pathogens such as C. acutatum, Alternaria alternata, Elsinoë fawcettii, Diaporthe citri, and Mycosphaerella citri to azoxystrobin and pyraclostrobin have been determined (36). Most isolates of the different pathogens were sensitive to the QoIs except for A. alternata, which has mycelia tolerant to azoxystrobin (36). More recently, resistance of $A$. alternata to QoI fungicides was reported (58), resulting in control failures.

Because black spot is an emerging disease in Florida, the establishment of baseline sensitivity of G. citricarpa isolates from Florida to QoI fungicides will help to monitor pathogen shifts in sensitivity to these fungicides. This baseline information could con- tribute to the long-term effectiveness of current spray programs in Florida. The objective of this research was to evaluate QoI fungicides for in vitro activity and to determine the baseline sensitivity of $G$. citricarpa isolates from Florida.

\section{Materials and Methods}

Fungal isolates and storage. Eighty-six isolates of G. citricarpa from Collier, Hendry, and Polk Counties, where CBS is currently present, were evaluated for their in vitro sensitivity to the fungicides azoxystrobin and pyraclostrobin. The isolates were taken from hard spot, early virulent spot, and pycnidia. Briefly, symptomatic fruit were washed, surface disinfested in $5 \% \mathrm{NaOCl}$, rinsed in sterile deionized water (SDW), and air dried for 2 to $3 \mathrm{~h}$. The lesions were excised, placed in $50 \%$ ethanol for $30 \mathrm{~s}$, then in $5 \% \mathrm{NaOCl}$, then rinsed with SDW for $7 \mathrm{~min}$ and dried in a laminar air-flow hood. Sections of the lesions were placed on carrot agar (CA; 42) or potato dextrose agar (PDA) and incubated at room temperature with $12 \mathrm{~h}$ of light. When pycnidia were used for isolations, they were placed on moistened sterile filter paper and incubated overnight. Pycnidia were selected under the stereomicroscope and individually placed on CA. All isolations were incubated for 5 to 6 days. Isolates with typical morphology were placed on an indicator medium, oatmeal agar, and observed for a yellow halo (5). Each isolate was also subjected to polymerase chain reaction (PCR) identification with the primer sets NP-Br-ITS-Gc and NPBr-ITS-Gm, as described by Peres et al. (42). Single-spore isolates were produced for all assays. For single-spore isolation, isolates cultured under a 12-h light cycle for 2 to 3 weeks were flooded with SDW containing $0.02 \%$ Tween 20 . The resulting suspensions were washed with SDW by centrifuging at $5,000 \mathrm{rpm}$ for $5 \mathrm{~min}$. This washing process was repeated twice. The final conidial concentration was adjusted to $10^{6}$ spores $/ \mathrm{ml}$ using a hemocytometer. Conidial suspensions ( $20 \mu \mathrm{l}$ each) were spread on PDA and incubated at $25^{\circ} \mathrm{C}$ for 3 days. Germinated conidia were then picked up using a flame-sterilized needle under a stereomicroscope and transferred to PDA. For long-term storage, all isolates were kept on sterile filter paper in sealed plastic containers containing $\mathrm{CaSO}_{4}$ desiccant at $-20^{\circ} \mathrm{C}$. For mycelium and conidia production, G. citricarpa isolates were transferred to half-strength PDA and grown for 14 days at $25^{\circ} \mathrm{C}$.

Mycelium growth inhibition assay. Commercial formulations of azoxystrobin (Abound) and pyraclostrobin (Headline SC) were used. The fungicides were diluted in SDW to prepare stock solutions of the active ingredient at 100 and $1 \mathrm{mg} / \mathrm{ml}$. From the 1 $\mathrm{mg} / \mathrm{ml}$ stock, 3.5, 35, and $350 \mu \mathrm{l}$ were added and, from the 100 $\mathrm{mg} / \mathrm{ml}$ stock, 35 and $350 \mu \mathrm{l}$ were added to molten half-strength PDA $(3,500 \mathrm{ml})$ after cooling to $55^{\circ} \mathrm{C}$ to obtain final concentrations of active ingredient at $0.001,0.01,0.1,1$, and $10 \mu \mathrm{g} / \mathrm{ml}$. Unamended medium was used as the control.

Amended PDA (20 ml) was poured into $100-\mathrm{mm}$-diameter petri dishes using a sterile bottle top dispenser (Fisherbrand). In all, 86 isolates were evaluated for sensitivity to the QoI fungicides. Mycelial plugs, $3 \mathrm{~mm}$ in diameter, from the actively growing area of the fungal colony were placed in the center of each plate. Three replicates were used for each fungicide concentration. Plates were incubated at $25^{\circ} \mathrm{C}$ for 14 days under continuous light, and colony diameter was determined as the average of two perpendicular measurements for each of the 86 isolates. The diameter of the mycelial plug was subtracted from the average colony diameter for each replicate. The percent inhibition was calculated relative to the growth of the unamended control for each isolate growing in the fungicide-amended plates.

Effect of SHAM and QoI fungicides on mycelial growth. Fifteen G. citricarpa isolates were tested to determine whether SHAM affected the response of fungal growth to azoxystrobin and pyraclostrobin. SHAM was dissolved in methanol at $0.1 \mathrm{mg} / \mathrm{ml}$. The amount of methanol in the media was $0.1 \%$ (vol $/ \mathrm{vol})$. Halfstrength PDA $(900 \mathrm{ml})$ was amended with 9 and $90 \mathrm{mg}$ of SHAM to obtain final concentrations of 10 and $100 \mu \mathrm{g} / \mathrm{ml}$. The effect of SHAM at 10 and $100 \mu \mathrm{g} / \mathrm{ml}$ on fungal growth was evaluated in 
combination with final fungicide concentrations of $0,0.001,0.01$, $0.1,1$, and $10 \mu \mathrm{g} / \mathrm{ml}$. Percent growth inhibition was based on comparison with the growth in SHAM plates with no fungicide. Inoculation method and measurements were done as described above.

Spore inhibition assay. Isolates of G. citricarpa were cultured on half-strength PDA for 14 days. Then, conidia were washed off using $4 \mathrm{ml}$ of sterile water with $0.02 \%$ Tween 20 . The suspension was centrifuged at 5,000 rpm for $5 \mathrm{~min}$, resuspended, and centrifuged three more times each for $5 \mathrm{~min}$ and the conidial concentration was adjusted to $10^{6}$ spores $/ \mathrm{ml}$ using a hemacytometer.

The germination medium consisted of $2 \%$ 'Valencia' orange juice ( $\mathrm{pH} \mathrm{4.0)}$ and was prepared to stimulate conidial germination (31). Germination was assessed on hydrophobic slides (Fisher Scientific) and each well contained $10 \mu \mathrm{l}$ of liquid $(33,37)$. Prior their addition to the wells, 10-fold serial dilutions of QoI fungicides of 0.001 to $1 \mu \mathrm{g} / \mathrm{ml}$ were prepared. Each well received $7.5 \mu \mathrm{l}$ of $2 \%$ 'Valencia' juice, $1.25 \mu \mathrm{l}$ of the corresponding fungicide concentration, and $1.25 \mu \mathrm{l}$ of the adjusted conidial suspension. Control wells contained $1.25 \mu \mathrm{l}$ of SDW instead of the fungicide. Hence, the suspension in each well had a 3:1 ratio of 'Valencia' orange juice to fungicide and conidia. Hydrophobic slides were placed into a petri dish filled with water at the bottom to prevent desiccation and incubated at $23^{\circ} \mathrm{C}$ for $20 \mathrm{~h}$. Then, 100 conidia were observed under the microscope at $\times 400$ to determine the percent germinated conidia. A conidium was considered germinated if the germ tube was equal to or longer than the length of the conidium. The percent spore inhibition was calculated for each of the 86 isolates, fungicide, and experiment combinations.

Effect of SHAM and QoI fungicides on spore germination. The same isolates used to determine the effect of SHAM on mycelial growth were used to evaluate the effect of SHAM on spore germination inhibition. Different SHAM concentrations were tested prior to the addition of QoI fungicides. A stock suspension of SHAM at $0.1 \mathrm{mg} / \mathrm{ml}$ was serially diluted to obtain final concentrations in each well of SHAM at $10,25,50$, and $100 \mu \mathrm{g} / \mathrm{ml}$. The content of methanol in each well was $0.1 \%$ (vol/vol). Each well received $7.5 \mu \mathrm{l}$ of $2 \%$ 'Valencia' orange juice, $1.25 \mu \mathrm{l}$ of the adjusted spore suspension, and $1.25 \mu \mathrm{l}$ of the corresponding SHAM concentration. Control wells received $1.25 \mu \mathrm{l}$ of SDW instead of SHAM. Thus, the suspension in each well had a 3:1 ratio of Valencia orange juice to medium.

The effect of SHAM at $10 \mu \mathrm{g} / \mathrm{ml}$ on spore germination was evaluated in combination with final QoI fungicide concentrations of 0 , $0.001,0.01,0.1$, and $1 \mu \mathrm{g} / \mathrm{ml}$. To maintain a 3:1 ratio of 'Valencia' juice to SHAM, fungicide and conidia, the amount of medium added to each well was modified. Therefore, each well received 7.5 $\mu \mathrm{l}$ of $2 \%$ orange juice, $0.83 \mu \mathrm{l}$ of each fungicide concentration, $0.83 \mu \mathrm{l}$ of SHAM, and $0.83 \mu \mathrm{l}$ of the adjusted conidial suspension. Control wells received $0.83 \mu \mathrm{l}$ of SDW instead of the fungicide. After the slides were loaded with the suspension, the same procedure as described in the spore inhibition assay was followed. Percent inhibition was determined for each isolate-fungicide-experiment combination.

Azoxystrobin technical-grade versus commercial formulation and the effect of SHAM on mycelium inhibition. To test whether or not there was a difference between commercial formulation of azoxystrobin (Abound) or technical-grade active ingredient, 10 isolates of $G$. citricarpa were tested against the two forms

Table 1. Primers designed in the study to amplify the cyt $b$ gene from Guignardia citricarpa genomic DNA

\begin{tabular}{ll}
\hline Primer & \multicolumn{1}{c}{ Sequence $\left(\mathbf{5}^{\prime}\right.$ to $\left.\mathbf{3}^{\prime}\right)$} \\
\hline Cytb3 & AGCTCCTAGAACACTTGTTTGAACTA \\
Cytb5 & TTAGGTTGGTCGTACAGTGAAAGTGAG \\
Cytb6 & TACCTATCTCACGACTAGCCAACTCAC \\
Cytb7 & GGGTGTAATTGCCAAATTACGGGA \\
Cytb8 & CATTTCACCCTAATTTGTTTGCGG \\
Cytb11 & TATGTACGAAAGGAAATGGGTAATCCG \\
Cytb12 & TATGACATAGGTGCTCTGTTTAAGGC \\
\hline
\end{tabular}

of the chemical. Azoxystrobin commercial formulation and technical-grade stock solutions of active ingredient at $100 \mu \mathrm{g} / \mathrm{ml}$ were diluted in water or acetone, respectively, and added to molten halfstrength PDA at $0,0.001,0.01,0.1,1$, and $10 \mu \mathrm{g} / \mathrm{ml}$. In addition, the effect of SHAM at $100 \mu \mathrm{g} / \mathrm{ml}$ added to commercial formulation and technical-grade azoxystrobin was also tested on mycelium growth inhibition. The dilution method was as described for the effect of SHAM on mycelium growth assay. Inoculation method, measurements and calculation of percent inhibition were done as described for the mycelium inhibition assay.

Calculation of effective concentration to reduce growth by $\mathbf{5 0 \%}$ and statistical analysis. For all experiments, there were three replications per isolate-fungicide concentration combination and each experiment was repeated twice. For mycelium inhibition assays, the effective concentration to reduce growth by $50 \%\left(\mathrm{EC}_{50}\right)$ was determined by fitting a four-parameter logistic (sigmoidal) function for azoxystrobin and a three-parameter function for pyraclostrobin. On the other hand, for spore-inhibition assays, $\mathrm{EC}_{50}$ was determined by fitting a three-parameter sigmoidal function for both QoIs. For all experiments, $\mathrm{EC}_{50}$ values were calculated using SigmaPlot (ver. 10.0; Systat Software Inc.).

To test for the homogeneity of variance, the standardized residuals were plotted against predicted values. In addition, the normality of the data distribution was tested with univariate analysis. Because variances were equal, data from different experiments were pooled to calculate the mean $\mathrm{EC}_{50}$ for each fungicide-isolate combination.

The effect of fungicide, isolate, experiment, and all the two-way interactions were investigated by an analysis of variance (ANOVA). Treatment means were separated using the least significant difference with PROC GLM (SAS 9.3; SAS Institute).

DNA extraction and sequence analysis of $\boldsymbol{c y t} \boldsymbol{b}$. The mycelium of isolate $\mathrm{Gc} 12$ was harvested from 5-day-old cultures on halfstrength PDA overlaid with a layer of cellophane. After grinding the mycelia in liquid nitrogen, genomic DNA (gDNA) was extracted using the DNeasy Plant Mini kit (Qiagen), purified using phenol/chloroform/isoamyl alcohol (25:24:1), and sequenced using the Ion Torrent Personal Genome Machine (PGM; 318 chip; Life Technologies). The sequence data were then assembled using the de Bruijn graph algorithm (62) embedded in the CLC Genomic Workbench (v5.0.1; CLC Bio) and analyzed by BlastN against the GenBank database. To fill the gaps between contigs, primers targeting the end of the contigs were designed (Cytb3/Cytb12 and Cytb5/Cytb6, Table 1). PCR reactions were performed in $25-\mu \mathrm{l}$ volumes containing 1 to $10 \mathrm{ng}$ of gDNA, $0.2 \mu \mathrm{M}$ primers, $0.2 \mathrm{mM}$ each dNTP, $1 \times$ PCR buffer, and $1 \mathrm{U}$ of HotStar Taq polymerase (Qiagen) with cycling conditions of $95^{\circ} \mathrm{C}$ for $5 \mathrm{~min}$; followed by 35 cycles of $94^{\circ} \mathrm{C}$ for $30 \mathrm{~s}, 56^{\circ} \mathrm{C}$ for $30 \mathrm{~s}$, and $72^{\circ} \mathrm{C}$ for $1 \mathrm{~min}$; and a final 5 -min extension at $72^{\circ} \mathrm{C}$. PCR products were cloned into the pGEN-T vector (Promega Crop.) and sequenced by the Interdisciplinary Center for Biotechnology Research (University of Florida). The partial $c y t b$ sequence was deposited in GenBank (accession number KC788404).

To identify the coding sequence of the partial $c y t b$, total RNA was extracted using the RNeasy Plant Mini kit (Qiagen) from mycelia harvested as above and reverse transcribed with the oligo $(\mathrm{dT})_{23} \mathrm{VN}$ primer using the ProtoScript AMV First-Strand cDNA Synthesis kit (New England BioLabs), according to the manufacturer's instructions. The resulting cDNA was analyzed by PCR using the primer pair KES126/KES115 (34), and PCR products were cloned and sequenced as above.

All G. citricarpa isolates in this study were sequenced to identify potential mutations in the hot spot, a highly conserved region of the cyt $b$ gene associated with QoI resistance where mutations, including G143, G137, and F129, may occur (23). Briefly, mycelia were crushed with pipette tips in tubes containing $20 \mu \mathrm{l}$ of extraction buffer from the Extract-N-Amp Plant kit (Sigma-Aldrich). Following incubation at $95^{\circ} \mathrm{C}$ for $10 \mathrm{~min}$, crushed mycelia were mixed with $20 \mu \mathrm{l}$ of dilution buffer. PCR reactions were performed as above using primers pairs Cytb7/Cytb8 and Cytb11/Cytb12 (Table 1) targeting regions containing G143 and G137, and F129, 
respectively, and 10 samples from each primer pair were arbitrarily selected for sequencing. Sequence alignment and the percent homology were performed using MEGA v5.10 (53).

\section{Results}

Inhibition of mycelial growth. The $\mathrm{EC}_{50}$ of $G$. citricarpa isolates to azoxystrobin and pyraclostrobin was determined and the ANOVA showed that the fungicide effect was highly significant $(P$ $<0.0001)$. No interactions between experiment, fungicide, and isolate were found (Table 2). The mean $\mathrm{EC}_{50}$ value of the 86 isolates for azoxystrobin was significantly higher $(P<0.0001)$ than the $\mathrm{EC}_{50}$ value for pyraclostrobin regardless of growth stage tested (Table 3). Azoxystrobin inhibited mycelial growth up to $73 \%$ at 1 $\mu \mathrm{g} / \mathrm{ml}$ but only $68 \%$ at $10 \mu \mathrm{g} / \mathrm{ml}$ (Fig. 1A). This reduction in
Table 3. Effective concentration of azoxystrobin and pyraclostrobin fungicides to inhibit mycelial growth and spore germination by $50 \%\left(\mathrm{EC}_{50}\right)$ of 86 Guignardia citricarpa isolates

\begin{tabular}{|c|c|c|}
\hline \multirow[b]{2}{*}{ Fungicide } & \multicolumn{2}{|c|}{ Mean EC $\mathrm{E}_{50} \mu \mathrm{g} / \mathrm{ml}^{\mathrm{z}}$} \\
\hline & Mycelium inhibition & Spore inhibition \\
\hline $\begin{array}{l}\text { Azoxystrobin } \\
\text { Pyraclostrobin }\end{array}$ & $\begin{array}{l}(0.002-0.26) 0.027 \mathrm{aA} \\
(0.002-0.03) 007\end{array}$ & $(0.001-0.03) 0.016 \mathrm{aB}$ \\
\hline
\end{tabular}

${ }^{\mathrm{z}}$ Average of two independent experiments. Numbers in parentheses indicate minimum and maximum mean $\mathrm{EC}_{50}$ value of mycelium and spore inhibition for each fungicide. Mean separation within column followed by the same lowercase letter are not significantly different according to $t$ test (least significant difference [LSD], $P \leq 0.05$ ). Mean separation within rows followed by the same uppercase letter are not significantly different according to $t$ test (LSD, $P \leq 0.05)$.

Table 2. $F$ statistics and $P$-values for the effect of azoxystrobin and pyraclostrobin on mycelium growth and spore germination inhibition of 86 Guignardia citricarpa isolates $^{\mathrm{z}}$

\begin{tabular}{|c|c|c|c|c|c|}
\hline \multirow[b]{2}{*}{ Factor } & \multirow[b]{2}{*}{ df } & \multicolumn{2}{|c|}{ Mycelium growth inhibition } & \multicolumn{2}{|c|}{ Spore germination inhibition } \\
\hline & & $\boldsymbol{F}$ & $P$ & $\boldsymbol{F}$ & $\boldsymbol{P}$ \\
\hline Experiment & 1 & 3.22 & 0.0762 & 1.07 & 0.3040 \\
\hline Fungicide & 1 & 22.89 & $\leq 0.0001$ & 158.0 & $\leq 0.0001$ \\
\hline Isolate & 85 & 0.99 & 0.5095 & 2.70 & $\leq 0.0001$ \\
\hline Experiment $\times$ fungicide & 1 & 3.65 & 0.0595 & 4.41 & 0.0387 \\
\hline Experiment $\times$ isolate & 85 & 0.97 & 0.5554 & 1.14 & $\overline{0.2673}$ \\
\hline Fungicide $\times$ isolate & 85 & 1.01 & 0.4790 & 2.75 & $\leq 0.0001$ \\
\hline
\end{tabular}

${ }^{\mathrm{z}}$ Significant effects are underlined.
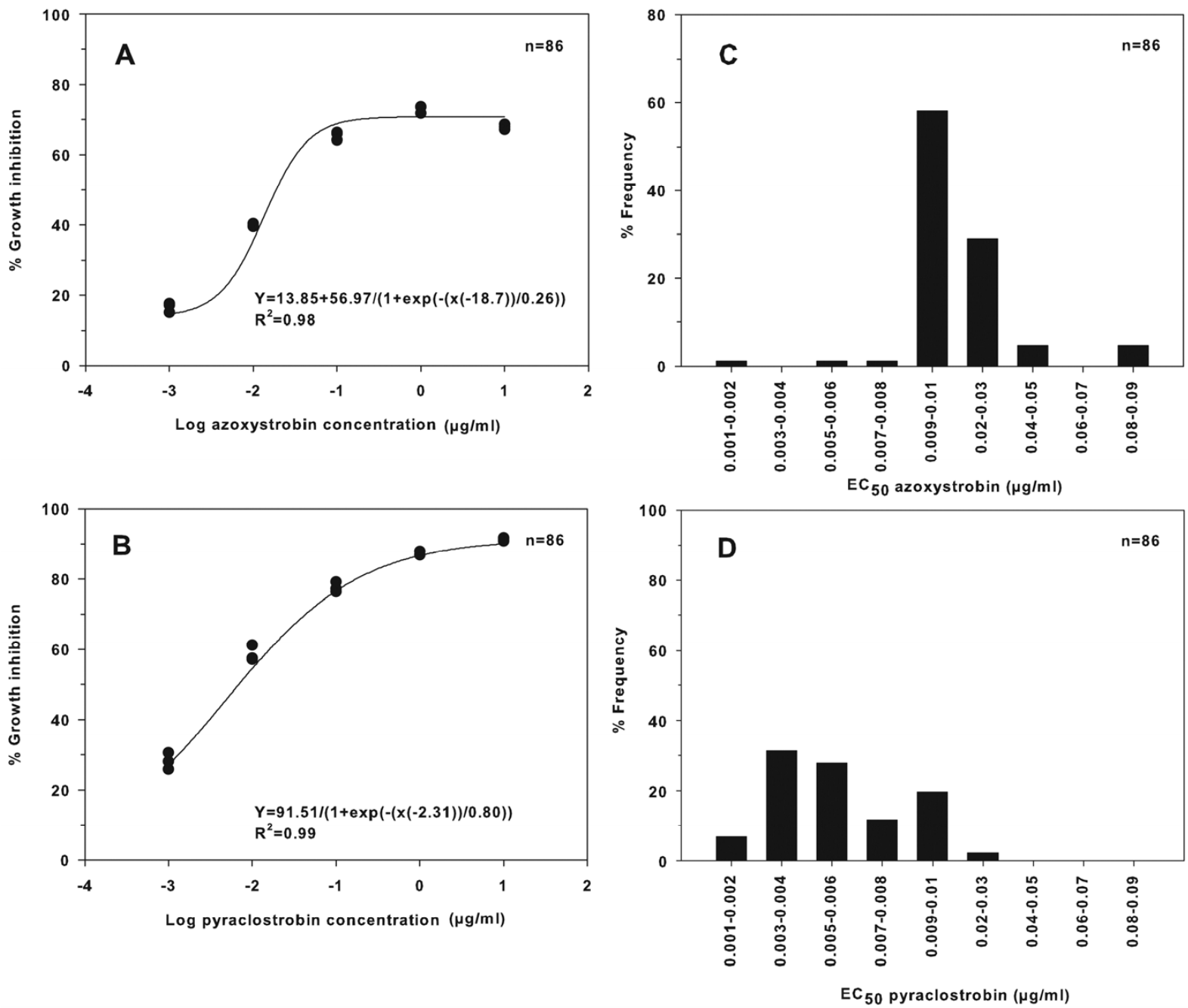

Fig. 1. A and B, Inhibition of mycelial growth of Guignardia citricarpa by different concentrations of azoxystrobin and pyraclostrobin, respectively. Points represent the average of two experiments and three replicates for each concentration. $\mathbf{C}$ and $\mathbf{D}$, Frequency distribution of the effective concentration of azoxystrobin and pyraclostrobin, respectively, needed to reduce mycelial growth by $50 \%\left(\mathrm{EC}_{50}\right)$ of $\mathrm{G}$. citricarpa isolates. 
growth inhibition at the highest concentration was not observed with pyraclostrobin. At $10 \mu \mathrm{g} / \mathrm{ml}$, growth inhibition was $91 \%$ for pyraclostrobin (Fig. 1B).

For azoxystrobin, $87 \%$ of the isolates had an $\mathrm{EC}_{50}$ between 0.009 and $0.03 \mu \mathrm{g} / \mathrm{ml}$ (Fig. 1C). For pyraclostrobin, however, the $\mathrm{EC}_{50}$ values were more evenly distributed over the range and $59 \%$ of isolates were between 0.003 and $0.006 \mu \mathrm{g} / \mathrm{ml}$, whereas another $31 \%$ of the isolates were between 0.007 and $0.01 \mu \mathrm{g} / \mathrm{ml}$ (Fig. 1D).

Effect of SHAM on mycelial growth. The addition of SHAM to media amended with azoxystrobin had no effect on the $\mathrm{EC}_{50}$ values for mycelial growth of the $15 \mathrm{G}$. citricarpa isolates at 10 $\mu \mathrm{g} / \mathrm{ml}(P=0.7136)$ or $100 \mu \mathrm{g} / \mathrm{ml}(P=0.0726)$. However, the addition of SHAM to pyraclostrobin had a significant effect on the $\mathrm{EC}_{50}$ values for mycelial growth at the same concentrations $(P=$ 0.017 and 0.006 , respectively; Table 4). No other factors or interactions between factors were significant. Although SHAM increased growth inhibition with azoxystrobin at $10 \mu \mathrm{g} / \mathrm{ml}$ (Fig. 2A), pairwise comparison indicated that there was no significant difference in the $\mathrm{EC}_{50}$ values and, for this reason, SHAM was not used to determine the baseline sensitivity of the $86 \mathrm{G}$. citricarpa isolates.

With the addition of SHAM to pyraclostrobin, a pattern of growth inhibition was observed that was similar to that with pyraclostrobin alone (Fig. 2B). The addition of SHAM at $10 \mu \mathrm{g} / \mathrm{ml}$ to the lowest concentration of pyraclostrobin inhibited growth more than SHAM at $100 \mu \mathrm{g} / \mathrm{ml}$ or pyraclostrobin alone. However, the $\mathrm{EC}_{50}$ values for both SHAM concentrations were the same, and pairwise comparison indicated that the addition of SHAM to pyraclostrobin had an effect on the $\mathrm{EC}_{50}$ values.

Inhibition of spore germination. Preliminary results from the spore germination test using azoxystrobin and pyraclostrobin at 0 , $0.001,0.01,0.1,1$, and $10 \mu \mathrm{g} / \mathrm{ml}$ indicated that $10 \mu \mathrm{g} / \mathrm{ml} \mathrm{com-}$ pletely inhibited spore germination. Thus, the highest fungicide concentration, $10 \mu \mathrm{g} / \mathrm{ml}$, was eliminated from all spore inhibition assays.

There was a significant effect for fungicide, isolate, and the fungicide-isolate and fungicide-experiment interactions (Table 2). Conidial germination was inhibited up to 91 and $94 \%$ by azoxystrobin and pyraclostrobin, respectively, at $1 \mu \mathrm{g} / \mathrm{ml}$ (Fig. 3A and B). No shift in the spore inhibition was observed at the highest concentration of azoxystrobin as occurred in the mycelium inhibition assay. For azoxystrobin, $66 \%$ of the isolates had an $\mathrm{EC}_{50}$ between 0.009 and $0.01 \mu \mathrm{g} / \mathrm{ml}$ (Fig. 3C) whereas $44 \%$ of the isolates had an $\mathrm{EC}_{50}$ between 0.003 and $0.006 \mu \mathrm{g} / \mathrm{ml}$ for pyraclostrobin (Fig. 3D).

Effect of SHAM on spore germination. Different SHAM concentrations were tested prior to the addition of the QoI fungicides. SHAM completely inhibited spore germination at 25, 50, and 100 $\mu \mathrm{g} / \mathrm{ml}$. Crystals formed on the slides when SHAM was added at $100 \mu \mathrm{g} / \mathrm{ml}$. Apparently, there is a reaction between the acid in the orange juice and the high concentration of SHAM which induced crystal formation.

Table 4. Mean effective concentration of azoxystrobin and pyraclostrobin with and without salicylhydroxamic acid (SHAM) to inhibit mycelial growth and spore germination by $50 \%\left(\mathrm{EC}_{50}\right)$ of 15 Guignardia citricarpa isolates

\begin{tabular}{lcc}
\hline & \multicolumn{2}{c}{ EC $_{\mathbf{5 0}} \boldsymbol{\mu g} / \mathbf{m l}^{\mathbf{y}}$} \\
\cline { 2 - 3 } Experiment $^{\mathbf{z}}$ & Azoxystrobin & Pyraclostrobin \\
\hline Mycelium & $0.017 \mathrm{a}$ & $0.008 \mathrm{a}$ \\
No SHAM & $0.016 \mathrm{a}$ & $0.005 \mathrm{~b}$ \\
SHAM $(10 \mu \mathrm{g} / \mathrm{ml})$ & $0.013 \mathrm{a}$ & $0.005 \mathrm{~b}$ \\
SHAM $(100 \mu \mathrm{g} / \mathrm{ml})$ & $0.015 \mathrm{a}$ & $0.006 \mathrm{a}$ \\
Spore & $0.016 \mathrm{a}$ & $0.005 \mathrm{a}$ \\
No SHAM & & \\
SHAM $(10 \mu \mathrm{g} / \mathrm{ml})$ &
\end{tabular}

${ }^{y}$ Mean separation within column followed by the same letter are not significantly different according to $t$ test (least significant difference, $P \leq$ 0.05 ) for each independent experiment.

z Two independent experiments: mycelium and spore inhibition.
SHAM at $10 \mu \mathrm{g} / \mathrm{ml}$ was selected for further tests of activity on spore germination inhibition when added to the QoIs. An ANOVA indicated that SHAM had no effect on the sensitivity of conidial germination when added to azoxystrobin and pyraclostrobin $(P=$ 0.3849 and 0.5887 , respectively; data not shown). Isolates had a significant effect $(P=0.0007)$ for azoxystrobin; however, interactions between factors were not significant for either fungicide (data not shown). The mean $\mathrm{EC}_{50}$ value for the isolates tested with azoxystrobin only was $0.015 \mu \mathrm{g} / \mathrm{ml}$ and, with SHAM, was 0.016 $\mu \mathrm{g} / \mathrm{ml}$. When pyraclostrobin was used alone, the mean $\mathrm{EC}_{50}$ was $0.006 \mu \mathrm{g} / \mathrm{ml}$ and the $\mathrm{EC}_{50}$ mean with SHAM was $0.005 \mu \mathrm{g} / \mathrm{ml}$ (Table 4). The percent spore inhibition when azoxystrobin or pyraclostrobin was used alone was very similar to the inhibition when SHAM was added to the fungicides (Fig. 4A and B). Without SHAM, the maximum spore germination inhibition was $93 \%$ for azoxystrobin and $92 \%$ for pyraclostrobin. With SHAM at 10 $\mu \mathrm{g} / \mathrm{ml}$, the maximum spore germination inhibition was $95 \%$ and 97\% for azoxystrobin and pyraclostrobin, respectively (Fig. 4A and B).

Azoxystrobin technical-grade versus commercial formulation and the effect of the different grades and SHAM on mycelium inhibition. No significant effect on the $\mathrm{EC}_{50}$ values between azoxystrobin technical-grade versus commercial formulation was demonstrated by ANOVA $(P=0.9939$; Table 5$)$. Also, no significant effect of the experiment or isolate was found and interactions between factors were not significant (data not shown).

The percent mycelium inhibition by both azoxystrobin formulations was similar at the different concentrations. For commercial
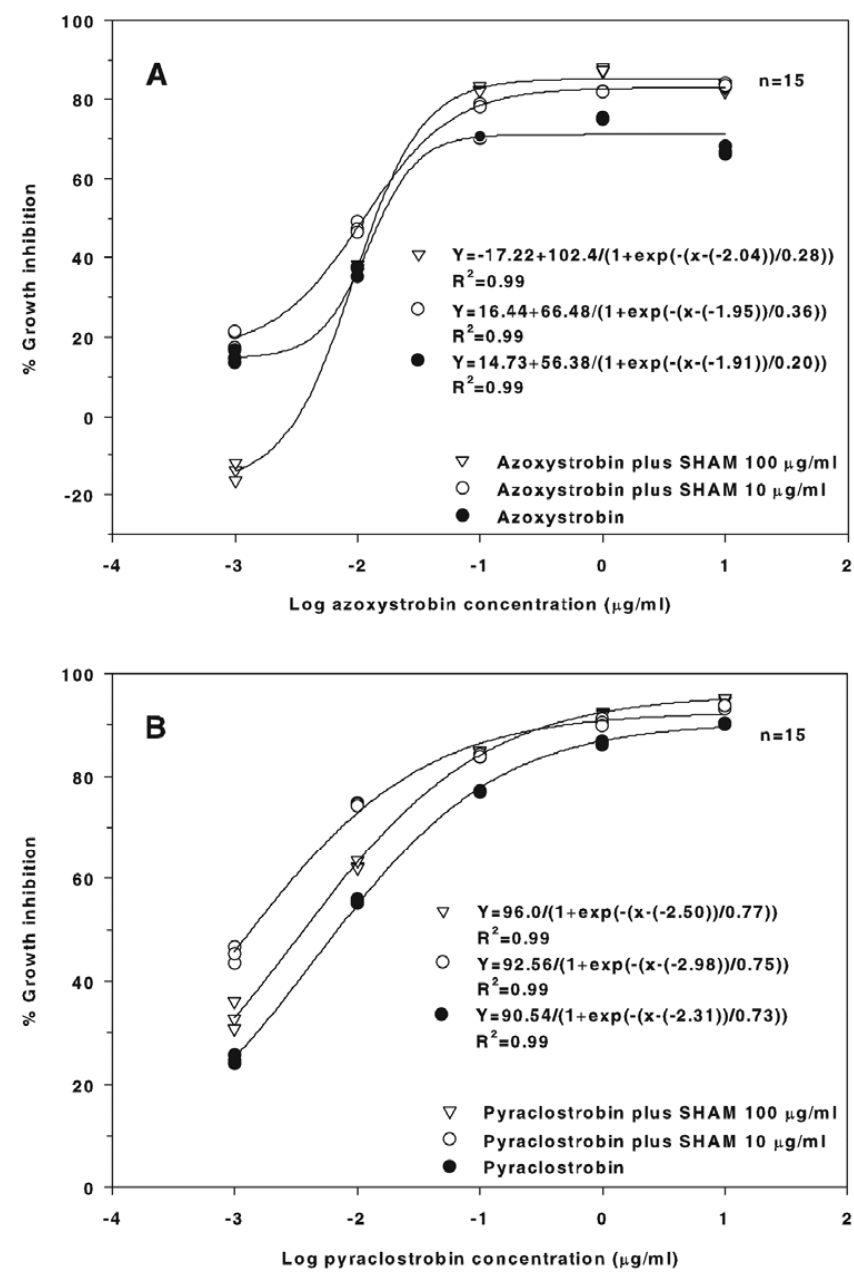

Fig. 2. A and B, Effect of salicylhydroxamic acid (SHAM) on the activity of azoxystrobin and pyraclostrobin, respectively, on mycelial growth of Guignardia citricarpa isolates. Points represent the average of two experiments and three replicates for each concentration. 
product at $1 \mu \mathrm{g} / \mathrm{ml}$, there was a $74 \%$ inhibition but, when the concentration was increased to $10 \mu \mathrm{g} / \mathrm{ml}$, inhibition was only $67 \%$. The same trend was also observed when using technical grade: at 1 $\mu \mathrm{g} / \mathrm{ml}$, there was $76 \%$ inhibition of mycelial growth but, at 10 $\mu \mathrm{g} / \mathrm{ml}$, the inhibition was only $69 \%$ (Fig. $5 \mathrm{~A}$ ).

The effect of SHAM at $100 \mu \mathrm{g} / \mathrm{ml}$ added to azoxystrobin technical-grade and commercial formulation was also tested. There was no effect of the addition of SHAM to technical-grade or commercial formulation as determined by ANOVA $(P=0.2006)$. However, pairwise comparison of $\mathrm{EC}_{50}$ values from technical grade with or without SHAM were significant $(P=0.0001$; Table 5), indicating that the addition of SHAM did affect the $\mathrm{EC}_{50}$ value of azoxystrobin technical grade.

Mycelial growth was stimulated when SHAM was added to the lowest rate of azoxystrobin commercial formulation. Nonetheless, mycelial growth inhibition by azoxystrobin commercial formulation at $1 \mu \mathrm{g} / \mathrm{ml}$ with SHAM was $88 \%$ but, at $10 \mu \mathrm{g} / \mathrm{ml}$, the inhibition was slightly less at $81 \%$. The growth inhibition by technical grade at 1 $\mu \mathrm{g} / \mathrm{ml}$ with SHAM was $83 \%$ and, at $10 \mu \mathrm{g} / \mathrm{ml}$, in contrast to the commercial formulation, the inhibition was higher, 91\% (Fig. 5B). Despite SHAM, growth inhibition was higher when the maximum rate of azoxystrobin technical grade was used; it had no significant effect on the $\mathrm{EC}_{50}$ values of either formulation of azoxystrobin.
Sequence analysis of $\boldsymbol{c y t} \boldsymbol{b}$. BlastN analysis revealed that three contigs $(1,129,1,581$, and 5,319 bp) shared high sequence identity with the $c y t$ t gene of G. bidwellii (GenBank accession JF785545; E-value $\left.<5 \mathrm{e}^{-109}\right)$. After PCR amplification and sequencing using Cytb3/Cytb12 and Cytb5/Cytb6 primers, a partial cyt $b$ gene of $8,546 \mathrm{bp}$ was generated. In addition, the coding sequence of the partial $c y t b$ gene was obtained using reverse-transcription PCR amplifying a 504-bp fragment encoding for the amino acid residues 99 to 266 (data not shown). The partial cyt b gene of G. citricarpa contains three introns between amino acid residues 99 and 259 (Fig. 6; Supplementary Figure 1). The first intron of 3,328 bp is inserted after the codon encoding a tyrosine residue at position 132 (Y132). The second intron of $943 \mathrm{bp}$ is inserted after the codon encoding a proline residue at position 135 (P135). The third intron is inserted after the codon encoding a glycine residue at position 143 (G143) (Fig. 6). All three introns belonged to the group I intron family (12). To determine whether all G. citricarpa isolates possessed the intron after amino acid position 143, PCR reactions using Cytb7/8 and Cytb11/12 primers amplified 594- and 1,323-bp fragments, respectively, from all tested $G$. citricarpa isolates (data not shown). Sequencing results from 10 arbitrarily selected isolates also revealed $100 \%$ sequence identity with the corresponding sequence of isolate Gc12 in both regions and con-
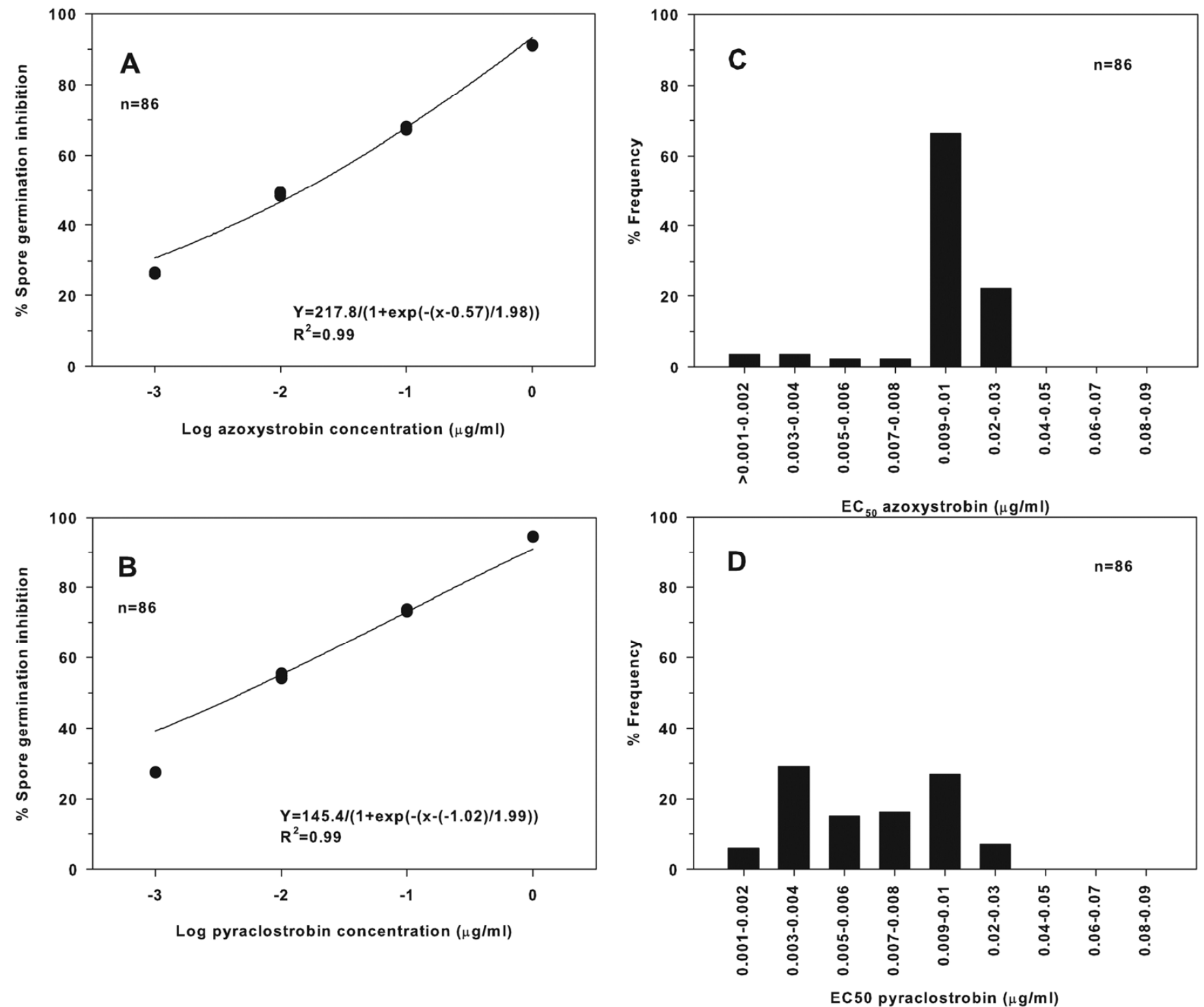

Fig. 3. A and B, Inhibition of spore germination of Guignardia citricarpa by different concentrations of azoxystrobin and pyraclostrobin, respectively. Points represent the average of two experiments and three replicates for each concentration. $\mathbf{C}$ and $\mathbf{D}$, Frequency distribution of the effective concentration of azoxystrobin and pyraclostrobin, respectively, to reduce spore germination by $50 \%\left(\mathrm{EC}_{50}\right)$ of $\mathrm{G}$. citricarpa isolates. 

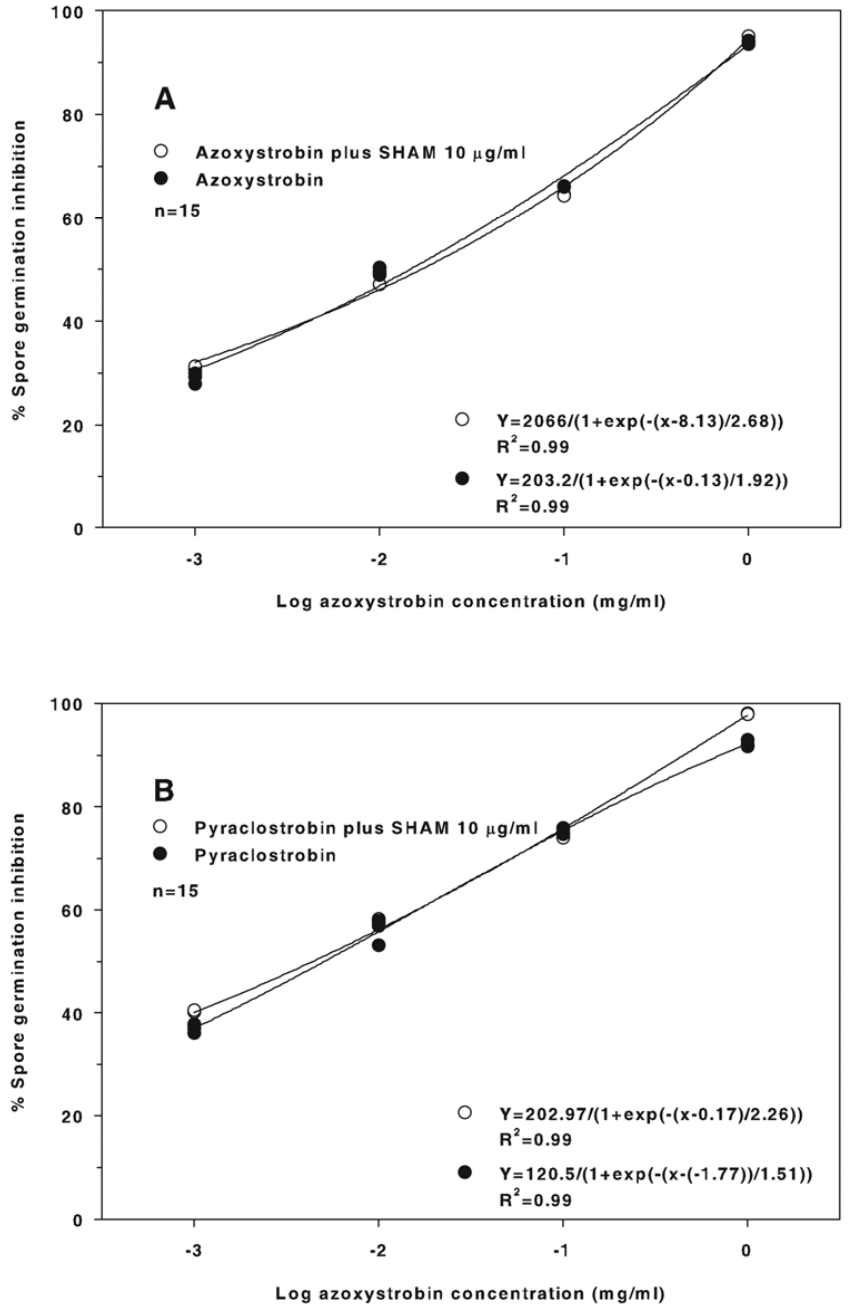

Fig. 4. A and B, Effect of salicylhydroxamic acid (SHAM) on the activity of azoxystrobin and pyraclostrobin, respectively, on spore germination of Guignardia citricarpa isolates. Points represent the average of two experiments and three replicates for each concentration.

Table 5. Mean effective concentration of azoxystrobin fungicide and technical-grade azoxystrobin, with and without salicylhydroxamic acid (SHAM), that inhibited mycelial growth of 10 Guignardia citricarpa isolates by $50 \%\left(\mathrm{EC}_{50}\right)$

\begin{tabular}{lcc}
\hline & \multicolumn{2}{c}{$\mathbf{E C}_{\mathbf{5 0}} \mathbf{\mu g} / \mathbf{m l}^{\mathbf{z}}$} \\
\cline { 2 - 3 } & Azoxystrobin technical & Azoxystrobin commercial \\
\hline No SHAM & $0.017 \mathrm{aA}$ & $0.016 \mathrm{aA}$ \\
SHAM & $0.013 \mathrm{bA}$ & $0.014 \mathrm{aA}$ \\
\hline
\end{tabular}

${ }^{\mathrm{z}}$ Mean separation within columns followed by the same lowercase letter are not significantly different according to $t$ test (least significant difference [LSD], $P \leq 0.05$ ). Mean separation within rows followed by the same uppercase letter are not significantly different according to $t$ test $(\mathrm{LSD}, P \leq 0.05)$

firmed that no substitution was observed in these isolates (data not shown).

\section{Discussion}

In this study, we established the baseline sensitivity of G. citricarpa isolates from Florida to azoxystrobin and pyraclostrobin. $\mathrm{EC}_{50}$ values for mycelium inhibition of other citrus pathogens to azoxystrobin were higher than $G$. citricarpa when compared with our results $\left(\mathrm{EC}_{50}\right.$ mean $\left.=0.027 \mu \mathrm{g} / \mathrm{ml}\right)$. The mean $\mathrm{EC}_{50}$ of $E$. fawcettii was $0.06 \mu \mathrm{g} / \mathrm{ml}$, the mean $\mathrm{EC}_{50}$ for $C$. acutatum was 0.40 $\mu \mathrm{g} / \mathrm{ml}$, the D. citri $\mathrm{EC}_{50}$ mean was $0.08 \mu \mathrm{g} / \mathrm{ml}$, and the $\mathrm{EC}_{50}$ mean for $M$. citri was $1.62 \mu \mathrm{g} / \mathrm{ml}$ (36). Vega et al. (58) found a mean
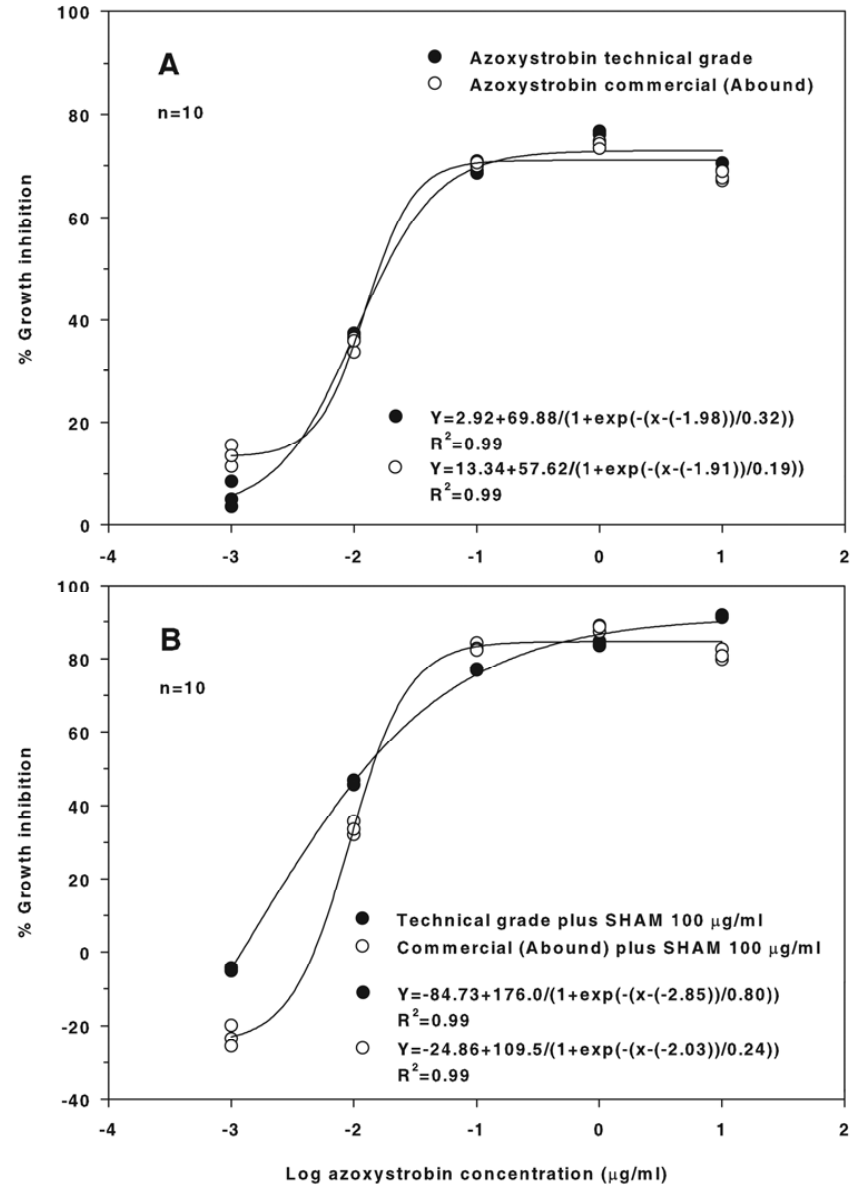

Fig. 5. A, Inhibition of mycelium growth of Guignardia citricarpa by different concentrations of azoxystrobin technical-grade and commercial formulation. Points represent the average of two experiments and three replicates for each concentration. B, Effect of salicylhydroxamic acid (SHAM) on the activity of technical-grade and commercial formulation of azoxystrobin on mycelial growth of Guignardia citricarpa isolates. Points represent the average of two experiments and three replicates for each concentration.

$\mathrm{EC}_{50}$ of $0.44 \mu \mathrm{g} / \mathrm{ml}$ for QoI-sensitive conidia of A. alternata for azoxystrobin. Although Mondal et al. (36) reported $\mathrm{EC}_{50}$ values higher than $100 \mu \mathrm{g} / \mathrm{ml}$ from A. alternata mycelium, the values from sensitive isolates' conidia were much lower, indicating that mycelium of this pathogen is insensitive to azoxystrobin $(36,58)$. In addition, the baseline for mycelium of Plasmopara viticola isolates showed a large range of $\mathrm{EC}_{50}$ values, from 0.04 to 0.78 $\mu \mathrm{g} / \mathrm{ml}$ (59). The most similar baseline to $G$. citricarpa for azoxystrobin was from sensitive isolates of $C$. graminicola, which had a range of $\mathrm{EC}_{50}$ values from 0.05 to $0.1 \mu \mathrm{g} / \mathrm{ml}$ (4). In vitro activity of G. citricarpa to azoxystrobin was also evaluated in Brazil; even at higher doses of azoxystrobin $(10 \mu \mathrm{g} / \mathrm{ml})$, mycelium growth could not be totally inhibited and some isolates had a decrease in mycelium inhibition when compared with the lowest concentration of the fungicide $(1 \mu \mathrm{g} / \mathrm{ml} ; 43)$. Similar results were obtained in this study, where less inhibition was observed at 10 $\mu \mathrm{g} / \mathrm{ml}$ with all the isolates tested. On the other hand, the same authors reported complete inhibition of sporulation by azoxystrobin.

Few reports on in vitro activity of pyraclostrobin are available. In this study, isolates of $G$. citricarpa were highly sensitive to pyraclostrobin $\left(\mathrm{EC}_{50}\right.$ mean $\left.=0.007 \mu \mathrm{g} / \mathrm{ml}\right)$. Mondal et al. (36) established the baseline sensitivity of five fungal citrus pathogens and their $\mathrm{EC}_{50}$ values to pyraclostrobin were greater than the values reported in this study for $G$. citricarpa.

Spore germination is a fungal stage particularly sensitive to QoIs (8). In this study, the $\mathrm{EC}_{50}$ values for conidia of $G$. citricarpa to azoxystrobin were lower $\left(\mathrm{EC}_{50}\right.$ mean $\left.=0.016 \mu \mathrm{g} / \mathrm{ml}\right)$ than the $\mathrm{EC}_{50}$ values reported for conidial germination of Erysiphe graminis f. sp. 


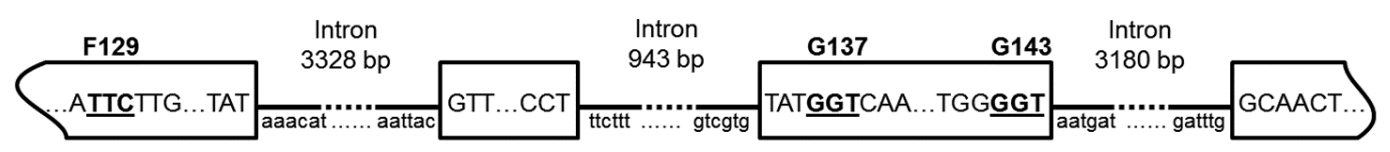

Fig. 6. Partial structure at the exon-intron junction in the cytochrome $b$ gene of Guignardia citricarpa. Boxes indicate exons and lines indicate introns. Lengths of exons and introns are not to scale.

tritici on cereals, which ranged from 0.022 to $0.235 \mu \mathrm{g} / \mathrm{ml}$ (14). Our results showed that the baseline for mycelial growth was higher than for spore germination, implying that G. citricarpa conidia are more sensitive to QoI fungicides. In other studies, spore germination has also been shown to be more sensitive than mycelium to pyraclostrobin. The $\mathrm{EC}_{50}$ values of pyraclostrobin for conidia of E. necator were similar to our results $\left(\mathrm{EC}_{50}\right.$ mean $=$ $0.008 \mu \mathrm{g} / \mathrm{ml}$ ), ranging from 0.0016 to $0.010 \mu \mathrm{g} / \mathrm{ml}$ with a mean of $0.0044 \mu \mathrm{g} / \mathrm{ml}(60)$.

Some fungal plant pathogens evade the toxic effects of QoI fungicides by the alternative respiration pathway, which allows the generation of ATP without electron transport through complex III and, thus, allows the fungus to survive even at high doses of fungicide $(38,63)$. It has been reported that residual growth of Magnaporthe grisea sustained by alternative respiration was involved in the spontaneous emergence of QoI-resistant cytochrome $b$ target site mutants (3). Nevertheless, for several fungal species, this rescue mechanism had little effect in the field when QoI fungicides were used to control the disease $(38,63)$. It has been proposed that, for those fungal species, plant antioxidants such as flavones present in the host can silence this mechanism during infection by quenching the reactive oxygen (2). Therefore, differences between in vitro and in vivo for the same pathogen are likely to be found (38). For this reason, the alternative respiration should be blocked for some pathogens by using SHAM during in vitro experiments.

In the current study, SHAM did not affect the activity of azoxystrobin. Neither mycelial growth nor spore germination was significantly affected by the addition of SHAM to the medium. Similar results were obtained with $C$. graminicola and Penicillium digitatum, where the addition of SHAM did not increase the activity to azoxystrobin $(4,30)$. Our results also indicated that the addition of SHAM to pyraclostrobin did affect the activity on mycelium growth, although the $\mathrm{EC}_{50}$ values were similar. However, spore germination was not affected by SHAM. As in our study, the addition of SHAM to pyraclostrobin significantly reduced the colony diameter of the citrus pathogen $D$. citri, even though $\mathrm{EC}_{50}$ values could not be calculated due to reversed inhibition at low doses of the fungicide (36). Thus, our results indicate that $G$. citricarpa is not using the alternative respiration pathway.

Interestingly, in our study, azoxystrobin at $10 \mu \mathrm{g} / \mathrm{ml}$ showed lower mycelium growth inhibition than at 1 or $0.1 \mu \mathrm{g} / \mathrm{ml}$. Thus, to evaluate whether or not the product formulation was influencing these results, technical-grade was compared with commercial formulation. There were no differences between the two formulations. The addition of SHAM slightly increased the inhibition at $10 \mu \mathrm{g} / \mathrm{ml}$; however, it did not affect their $\mathrm{EC}_{50}$ values. Although there is no evidence that $G$. citricarpa is using alternative respiration, it is hypothesized that the pathogen may be activating this pathway with azoxystrobin specifically at $10 \mu \mathrm{g} / \mathrm{ml}$ and SHAM is blocking this pathway, or else the mycelium is not taking up the fungicide well at higher concentrations and SHAM increases the permeability.

Overall, G. citricarpa isolates were very sensitive to azoxystrobin and pyraclostrobin. In other regions with CBS, azoxystrobin and pyraclostrobin were tested for field efficacy with positive results $(1,19,35,44,48)$.

Analysis of the $c y t b$ gene structure showed that a group I intron is located directly after G143 in the Florida G. citricarpa isolates (13). The group I introns always have the nucleotide $\mathrm{T}$ directly upstream from the $5^{\prime}$ splice site and the nucleotide $\mathrm{G}$ before the $3^{\prime}$ splice site $(12,13)$. Studies in Saccharomyces cerevisiae revealed that a mutation from a GGT (glycine) to GAT (aspartic acid) at the codon 256 of the $c y t b$ gene, which was two nucleotides upstream from the $5^{\prime}$ splice site of a group I intron, significantly interfered with pre-mRNA maturation processes, leading to a deficient and lethal protein $(10,16)$. The same exon/intron boundary with group I introns has been found in other filamentous fungi such as $A$. solani (23), B. cinerea (7), G. bidwellii (34), Monilia fructicola (26), Puccinia spp. (24), and Pyrenophora teres (51), in which resistance to QoI fungicides conferred by the G143A substitution has not been reported yet. Recently, Stammler et al. (52) found that there were introns in the G. citricarpa cyt $b$ gene but they were not identified. The size of the introns found in this study and by Stammler et al. (52) were very close but could not be compared for homology because the sequence was not available in GenBank. According to Stammler et al. (52), the risk of a G143A mutation in the $c y t b$ gene causing resistance to QoI fungicides is low for $G$. citricarpa due to the presence of an intron, and it is possible to conclude that there is a low risk for the Florida G. citricarpa population as well. It was recently reported that, in yeast, rescue mechanisms that could potentially reestablish respiration close to wild-type levels may exist for the G143A mutation in the presence of a group I intron (56). The three hypothesized mechanisms were the deletion of the intron, overexpression of genes coding for mitochondria metal ion carriers in the nucleus, or a second mitochondrial mutation to restore exon/intron splicing (56). The rescue mechanisms are untested in the field but it indicates that the inhibition of the G143A mutation is not absolute.

Although F129L and G137R mutations in the $c y t b$ gene have been reported to confer a low level of resistance to QoI fungicides, the efficacy of QoI fungicides on disease control in the greenhouse or in the field is not significantly affected $(39,49,51)$, indicating that the use of QoI fungicides to control G. citricarpa harboring a F129L or G137R mutation would be still effective.

When chemical control measures fail, it may be due to selection pressure for pathogen resistance. The high specificity of the mode of action of QoI fungicides together with sexual recombination that occurs in some fungal pathogens promote the selection of resistant strains after prolonged periods of pesticide use $(10,29)$. Several pathogens have become insensitive to QoI fungicides $(20,21,25$, 45,58 ) and the risk for $G$. citricarpa developing resistance is unknown. Because of the intron structure of the $c y t b$ gene of $G$. citricarpa, there is a low probability for the G143A mutation which confers a high level of resistance. These results agree with the fact that QoI fungicides have been used extensively in countries where CBS has been present for many years but there are no reports of QoI resistance to date. The baseline study will help monitor any population shifts in the future that may occur, probably due to mutations other than the G143A.

\section{Acknowledgments}

This research was partially funded by the United States Department of Agriculture Animal and Plant Health Inspection Service. We thank J. Rollins for his advice and assistance on this project and K. Rodrigues for her technical assistance.

\section{Literature Cited}

1. Almeida, T. 2009. Mancha preta dos citros: expressão dos sintomas em frutos pela inoculação com conidios e controle do agente causal (Guignardia citricarpa). Ph.D. dissertation, Universidade Estadual Paulista, São Paulo, Brazil.

2. Avila-Adame, C., and Köller, W. 2003. Characterization of spontaneous mutants of Magnaporthe grisea expressing stable resistance to the Qoinhibiting fungicide azoxystrobin. Curr. Genet. 42:332-338.

3. Avila-Adame, C., and Köller, W. 2003. Impact of alternative respiration and target-site mutations on responses of germinating conidia of Magnaporthe grisea to Qo-inhibiting fungicides. Pest Manage. Sci. 59:303-309. 
4. Avila-Adame, C., Olaya, G., and Köller, W. 2003. Characterization of Colletotrichum graminicola isolates resistant to strobilurin-related QoI fungicides. Plant Dis. 87:1426-1432.

5. Baayen, R. P., Bonants, P. J. M., Verkley, G., Carroll, G. C., van der Aa, H. A., de Weerdt, M., van Brouwershaven, I. R., Schutte, G. C., Maccheroni, W., Glienke de Blanco, C., and Azevedo, J. L. 2002. Nonpathogenic isolates of the citrus black spot fungus, Guignardia citricarpa, identified as a cosmopolitan endophyte of woody plants, G. mangiferae (Phyllosticta capitalensis). Phytopathology 92:464-477.

6. Baldassari, R. B., Wickert, E., and de Goes, A. 2008. Pathogenicity, colony morphology and diversity of isolates of Guignardia citricarpa and G. mangiferae isolated from Citrus spp. Eur. J. Plant Pathol. 120:103-110.

7. Banno, S., Yamashita, K., Fukumori, F., Okada, K., Uekusa, H., Takagaki, M., Kimura, M., and Fujimura, M. 2009. Characterization of QoI resistance in Botrytis cinerea and identification of two types of mitochondrial cytochrome $b$ gene. Plant Pathol. 58:120-129.

8. Bartlett, D. W., Clough, J. M., Godwin, J. R., Hall, A. A., Hamer, M., and Parr-Dobrzanski, B. 2002. The strobilurin fungicides. Pest Manage. Sci. 58:649-662.

9. Bonants, P. J. M., Carroll, G. C., de Weerdt, M., van Brouwershaven, I. R., and Baayen, R. P. 2003. Development and validation of a fast PCR-based detection method for pathogenic isolates of the citrus black spot fungus, Guignardia citricarpa. Eur. J. Plant Pathol. 109:503-513.

10. Brent, K. J., and Hollomon, D. W. 2007. Fungicide Resistance: The Assessment of Risk. Crop Life International, Brussels, Belgium.

11. Brentu, F. C., Oduro, K. A., Offei, S. K., Odamtten, G. T., Vicent, A., Peres, N. A., and Timmer, L. W. 2012. Crop loss, aetiology, and epidemiology of citrus black spot in Ghana. Eur. J. Plant Pathol. 133:657-670.

12. Burke, J. M. 1988. Molecular genetics of group I introns: RNA structures and protein factors required for splicing - a review. Gene 73:273-294.

13. Cech, T. R. 1988. Conserved sequences and structures of group I introns: building an active site for RNA catalysis - a review. Gene 73:259-271.

14. Chin, K. M., Chavaillaz, D., Kaesbohrer, M., Staub, T., and Felsenstein, F. G. 2001. Characterizing resistance risk of Erysiphe graminis f. sp. tritici to strobilurins. Crop Prot. 20:87-96.

15. da Silva-Pinhati, A. C. O., de Goes, A. D., Wickert, E., Almeida, T. F., and Machado, M. A. 2009. Citrus black spot: epidemiology and management. Rev. Laranja 30:45-64

16. De La Salle, H., Jacq, C., and Slonimski, P. P. 1982. Critical sequences within mitochondrial introns: pleiotropic mRNA maturase and cis-dominant signals of the box intron controlling reductase and oxidase. Cell 28:721-732.

17. Dewdney, M. M., Schubert, T. S., Estes, M. R., and Peres, N. A. 2013. Citrus black spot. Pages 81-85 in: 2013 Florida Citrus Pest Management Guide. M. E. Rogers and M. M. Dewdney, eds. University of Florida, Institute of Food and Agricultural Services, Gainesville.

18. Duan, Y., Liu, S., Ge, C., Feng, X., Chen, C., and Zhou, M. 2012. In vitro inhibition of Sclerotinia sclerotiorum by mixtures of azoxystrobin, SHAM, and thiram. Pestic. Biochem. Physiol. 103:101-107.

19. Fogliata, G. M., Muñoz, M. L., Rojas, A. A., and Ploper, D. 2011. Eficacia de tres estrobilurinas para el control de mancha rojiza (Guignardia mangiferae) y mancha negra (Guignardia citricarpa) en frutos de limón, en Tucumán, República Argentina. Rev. Ind. Agríc. Tucumán 88:37-45.

20. Fungicide Resistance Action Committee (FRAC). 2013. FRAC code list 2013: fungicides sorted by mode of action (including FRAC code numbering). http://www.frac.info/frac/index.htm

21. Gisi, U., Chin, K. M., Knapova, G., Küng Färber, R., Mohr, U., Parisi, S., Sierotzki, H., and Steinfeld, U. 2000. Recent developments in elucidating modes of resistance to phenylamide, DMI and strobilurin fungicides. Crop Prot. 19:863-872.

22. Gisi, U., and Sierotzki, H. 2008. Fungicide modes of action and resistance in downy mildews. Eur. J. Plant Pathol. 122:157-167.

23. Grasso, V., Palermo, S., Sierotzki, H., Garibaldi, A., and Gisi, U. 2006. Cytochrome $b$ gene structure and consequences for resistance to Qo inhibitor fungicides in plant pathogens. Pest Manage. Sci. 62:465-472.

24. Grasso, V., Sierotzki, H., Garibaldi, A., and Gisi, U. 2006. Characterization of the cytochrome $b$ gene fragment of Puccinia species responsible for the binding site of QoI fungicides. Pestic. Biochem. Physiol. 84:72-82.

25. Heaney, S. P., Hall, A. A., Davies, S. A., and Olaya, G. 2000. Resistance to fungicides in the QoI-STAR cross-resistance group: current perspectives. Pages 755-762 in: Conf. Proc. BCPC Conf. Pests Dis. Br. Crop Prot. Council, Surrey, UK.

26. Hily, J.-M., Singer, S. D., Villani, S. M., and Cox, K. D. 2011. Characterization of the cytochrome $b$ (cyt b) gene from Monilinia species causing brown rot of stone and pome fruit and its significance in the development of QoI resistance. Pest Manage. Sci. 67:385-396

27. Holtz, T. 2010. Risk assessment of Citrus spp. fruit as a pathway of the introduction of Guignardia citricarpa Kiely, the organism that causes citrus black spot disease. USDA-APHIS. Online publication. http://www.aphis. usda.gov/plant_health/plant_pest_info/citrus/downloads/black_spot/cbsrisk-assessment.pdf

28. Jin, L.-H., Chen, Y., Chen, C.-J., Wang, J.-X., and Zhou, M.-G. 2009. Activity of azoxystrobin and SHAM to four phytopathogens. Agric. Sci. China 8:835-842.

29. Jutsum, A. R., Heaney, S. P., Perrin, B. M., and Wege, P. J. 1998. Pesticide resistance: assessment of risk and the development and implementation of effective management strategies. Pestic. Sci. 54:435-446.

30. Kanetis, L., Förster, H., and Adaskaveg, J. E. 2008. Baseline sensitivities for new postharvest fungicides against Penicillium spp. on citrus and multiple resistance evaluations in $P$. digitatum. Plant Dis. 92:301-310.

31. Korf, H. J. G. 1998. Survival of Phyllosticta citricarpa, anamorph of the citrus black spot pathogen. M.Sc. dissertation, University of Pretoria, Pretoria, South Africa.

32. Kotzé, J. M. 1981. Epidemiology and control of citrus black spot in South Africa. Plant Dis. 65:945-950.

33. Kuo, K. C., and Hoch, H. C. 1996. Germination of Phyllosticta ampelicida pycnidiospores: prerequisite of adhesion to the substratum and the relationship of substratum wettability. Fungal Genet. Biol. 20:18-29.

34. Miessner, S., Mann, W., and Stammler, G. 2011. Guignardia bidwellii, the causal agent of black rot on grapevine has a low risk for QoI resistance. J. Plant Dis. Prot. 118:51-53.

35. Miles, A. K., Willingham, S. L., and Cooke, A. W. 2004. Field evaluation of strobilurins and a plant activator for the control of citrus black spot. Australas. Plant Pathol. 33:371-378.

36. Mondal, S. N., Bhatia, A., Shilts, T., and Timmer, L. W. 2005. Baseline sensitivities of fungal pathogens of fruit and foliage of citrus to azoxystrobin, pyraclostrobin, and fenbuconazole. Plant Dis. 89:1186-1194.

37. Noronha, M. D. A. 2002. Escala Diagramatica Para Avaliação da Mancha Preta em Folas de Citros e Efeito da Temperatura ed da Duração do Molhamento na Pré-penetração de Conidíos de Guignardia citricarpa Kiely [Phyllosticta citricarpa (McAlp.) van der Aa]. M.Sc. dissertation, Universidade de São Paulo, Piraciaba, Brazil

38. Olaya, G., and Köller, W. 1999. Baseline sensitivities of Venturia inaequalis populations to the strobilurin fungicide kresoxim-methyl. Plant Dis. 83:274 278.

39. Pasche, J. S., Piche, L. M., and Gudmestad, N. C. 2005. Effect of the F129L mutation in Alternaria solani on fungicides affecting mitochondrial respiration. Plant Dis. 89:269-278

40. Pasche, J. S., Wharam, C. M., and Gudmestad, N. C. 2004. Shift in sensitivity of Alternaria solani in response to QoI fungicides. Plant Dis. 88:181187.

41. Paul, I., van Jaarsveld, A. S., Korsten, L., and Hattingh, V. 2005. The potential global geographical distribution of citrus black spot caused by Guignardia citricarpa (Kiely): likelihood of disease establishment in the European Union. Crop Prot. 24:297-308.

42. Peres, N. A., Harakava, R., Carroll, G. C., Adaskaveg, J. E., and Timmer, L. W. 2007. Comparison of molecular procedures for detection and identification of Guignardia citricarpa and G. mangiferae. Plant Dis. 91:525-531.

43. Possiede, Y. M., Gabardo, J., Kava-Cordeiro, V., Galli-Terasawa, L. V., Azevedo, J. L., and Glienke, C. 2009. Fungicide resistance and genetic variability in plant pathogenic strains of Guignardia citricarpa. Braz. J. Microbiol. 40:308-313.

44. Rodríguez, V. A., Avanza, M. M., Mazza, S. M., and Itatí Giménez, L. 2010. Efecto del pyraclostrobin en el control de mancha negra de los cítricos. Summa Phytopathol. 36:334-337.

45. Rosenzweig, N., Atallah, Z. K., Olaya, G., and Stevenson, W. R. 2008. Evaluation of QoI fungicide application strategies for managing fungicide resistance and potato early blight epidemics in Wisconsin. Plant Dis. 92:561-568.

46. Schonbaum, G. R., Bonner, W. D., Storey, B. T., and Bahr, J. T. 1971. Specific inhibition of cyanide-insensitive respiratory pathway in plant mitochondria by hydroxamic acids. Plant Physiol. 47:124-128.

47. Schubert, T. S., Dewdney, M. M., Peres, N. A., Palm, M. E., Jeyaprakash, A., Sutton, B., Mondal, S. N., Wang, N.-Y., Rascoe, J., and Picton, D. D. 2012. First report of Guignardia citricarpa associated with citrus black spot on sweet orange (Citrus sinensis) in North America. Plant Dis. 96:1225.

48. Schutte, G. C., Mansfield, R. I., Smith, H., and Beeton, K. V. 2003. Application of azoxystrobin for control of benomyl-resistant Guignardia citricarpa on 'Valencia' oranges in South Africa. Plant Dis. 87:784-788.

49. Semar, M., Strobel, D., Koch, A., Klappach, K., and Stammler, G. 2007. Field efficacy of pyraclostrobin against populations of Pyrenophora teres containing the F129L mutation in the cytochrome $b$ gene. J. Plant Dis. Prot. 114:117-119.

50. Siedow, J. N., and Bickett, D. M. 1981. Structural features required for inhibition of cyanide-insensitive electron-transfer by propyl gallate. Arch. Biochem. Biophys. 207:32-39.

51. Sierotzki, H., Frey, R., Wullschleger, J., Palermo, S., Karlin, S., Godwin, J., and Gisi, U. 2007. Cytochrome $b$ gene sequence and structure of Pyrenoph ora teres and $P$. tritici-repentis and implications for QoI resistance. Pest Manage. Sci. 63:225-233.

52. Stammler, G., Schutte, G. C., Speakman, J., Miessner, S., and Crous, P. W. 2013. Phyllosticta species on citrus: risk estimation of resistance to QoI fungicides and identification of species with cytochrome $b$ gene sequences. Crop Prot. 48:6-12.

53. Tamura, K., Peterson, D., Peterson, N., Stecher, G., Nei, M., and Kumar, S. 2011. MEGA5: molecular evolutionary genetics analysis using maximum likelihood, evolutionary distance, and maximum parsimony methods. Mol. Biol. Evol. 28:2731-2739.

54. Timmer, L. W., Garnsey, S. M., and Broadbent, P. 2003. Diseases of citrus. 
In: Diseases of Tropical Fruit Crops. R. C. Ploetz, ed. CABI Publishing, Cambridge, MA.

55. Truter, M., Labuschagne, P. M., Kotzé, J. M., Meyer, L., and Korsten, L. 2007. Failure of Phyllosticta citricarpa pycnidiospores to infect Eureka lemon leaf litter. Australas. Plant Pathol. 36:87-93.

56. Vallières, C., Trouillard, M., Dujardin, G., and Meunier, B. 2011. Deleterious effect of the Qo inhibitor compound resistance-conferring mutation G143A in the intron-containing cytochrome $b$ gene and mechanisms for bypassing it. AEM 77:2088-2093.

57. Vanlerberghe, G. C., and McIntosh, L. 1997. Alternative oxidase: from gene to function. Annu. Rev. Plant Physiol. Plant Mol. Biol. 48:703-734

58. Vega, B., Liberti, D., Harmon, P. F., and Dewdney, M. M. 2012. A rapid resazurin-based microtiter assay to evaluate QoI sensitivity for Alternaria alternata isolates and their molecular characterization. Plant Dis.
96:1262-1270.

59. Wong, F. P., and Wilcox, W. F. 2000. Distribution of baseline sensitivities to azoxystrobin among isolates of Plasmopara viticola. Plant Dis. 84:275-281

60. Wong, F. P., and Wilcox, W. F. 2002. Sensitivity to azoxystrobin among isolates of Uncinula necator: baseline distribution and relationship to myclobutanil sensitivity. Plant Dis. 86:394-404.

61. Yonow, T., Hattingh, V., and de Villiers, M. 2013. CLIMEX modelling of the potential global distribution of the citrus black spot disease caused by Guignardia citricarpa and the risk posed to Europe. Crop Prot. 44:18-28.

62. Zerbino, D. R., and Birney, E. 2008. Velvet: algorithms for de novo short read assembly using de Bruijn graphs. Genome Res. 18:821-829.

63. Ziogas, B. N., Baldwin, B. C., and Young, J. E. 1997. Alternative respiration: a biochemical mechanism of resistance to azoxystrobin (ICIA 5504) in Septoria tritici. Pestic. Sci. 50:28-34. 